\title{
Targeting the Post-Irradiation Tumor Microenvironment in Glioblastoma via Inhibition of CXCL12
}

\author{
Frank A. Giordano ${ }^{1, *(\mathbb{D}, \text { Barbara Link }}{ }^{1}$, Martin Glas ${ }^{2}$, Ulrich Herrlinger ${ }^{3}$, Frederik Wenz ${ }^{4}$, \\ Viktor Umansky ${ }^{5,6}$, J. Martin Brown ${ }^{7}$ and Carsten Herskind ${ }^{1}$ (D) \\ 1 Department of Radiation Oncology, Universitätsmedizin Mannheim, Medical Faculty Mannheim, \\ Heidelberg University, 68167 Mannheim, Germany; barbara.link@medma.uni-heidelberg.de (B.L.); \\ carsten.herskind@medma.uni-heidelberg.de (C.H.) \\ 2 Division of Clinical Neurooncology, Department of Neurology and West German Cancer Center (WTZ), \\ University Hospital Essen and German Cancer Consortium, Partner Site University Hospital Essen, \\ University Duisburg-Essen, 45147 Essen, Germany; Martin.Glas@UK-Essen.de \\ 3 Division of Clinical Neurooncology, Department of Neurology, University of Bonn Medical Center, \\ 53105 Bonn, Germany; Ulrich.Herrlinger@ukbonn.de \\ 4 CEO, University Medical Center Freiburg, 79110 Freiburg, Germany; frederik.wenz@uniklinik-freiburg.de \\ 5 Skin Cancer Unit, German Cancer Research Center (DKFZ), 69120 Heidelberg, Germany; \\ v.umansky@dkfz.de \\ 6 Department of Dermatology, Venereology and Allergology, University Medical Center Mannheim, \\ Ruprecht-Karl University of Heidelberg, 68167 Mannheim, Germany \\ 7 Department of Neurology, Stanford University School of Medicine, Stanford, CA 94305, USA; \\ mbrown@stanford.edu \\ * Correspondence: Frank.Giordano@umm.de; Tel.: +49-621-383-6020; Fax: +49-621-383-3493
}

Received: 7 January 2019; Accepted: 20 February 2019; Published: 26 February 2019

\begin{abstract}
Radiotherapy is a mainstay in glioblastoma therapy as it not only directly targets tumor cells but also depletes the tumor microvasculature. The resulting intra-tumoral hypoxia initiates a chain of events that ultimately leads to re-vascularization, immunosuppression and, ultimately, tumor-regrowth. The key component of this cascade is overexpression of the CXC-motive chemokine ligand 12 (CXCL12), formerly known as stromal-cell derived factor 1 (SDF-1). We here review the role of CXCL12 in recruitment of pro-vasculogenic and immunosuppressive cells and give an overview on future and current drugs that target this axis.
\end{abstract}

Keywords: glioblastoma; radiotherapy; CXCL12

\section{Introduction}

Glioblastoma (GB, WHO Grade IV astrocytoma) is the most common malignant and most aggressive primary brain tumor. The incidence generally increases with age, and the median age of diagnosis is 64 years [1]. The age-adjusted incidence in the U.S. is approximately 3 per 100,000 persons, and survival time of patients diagnosed with GB is usually between 12 and 24 months, with less than $5 \%$ living up to 5 years [2]. Focal neurological deficits, symptoms of increased intracranial pressure, epilepsy, and cognitive dysfunction are prominent symptoms which may arise in any stage of the disease $[3,4]$. Key prognostic factors for survival include general factors such as age, clinical performance status and the extent of resection.

The presence or absence of a promoter methylation of the $\mathrm{O}^{6}$-methylguanine DNA methyltransferase (MGMT) has been shown to be of specific relevance for outcome as it may predict the response to chemotherapy and overall prognosis as a confirmed prognostic biomarker $[5,6]$. 
Treatment of GBM requires a multidisciplinary approach and, for more than a decade, patients with adequate performance scores and tumors amenable to resection undergo surgery and then combined external-beam radiotherapy (EBRT) and chemotherapy with the alkylating agent temozolomide followed by maintenance temozolomide, the 'Stupp protocol' [7]. Elderly or frail patients may, depending on molecular markers (MGMT), alternatively receive either radiotherapy alone, temozolomide alone, or short-course radiotherapy with or without temozolomide [8-10].

A recent randomized clinical phase III trial has shown survival benefits after treatment with a portable, non-invasive device that delivers low-intensity, intermediate-frequency, alternating electric fields to the brain and acts by reversing tumor growth by inhibiting cell division [11]. This therapy, commonly referred to as Tumor-Treating Fields (TTF), has evolved as an additional treatment modality on top of maintenance temozolomide chemotherapy, which is usually initiated after radiochemotherapy.

Despite their effectiveness in GB, all modalities exhibit characteristic adverse effects. Common complications from surgical resection are focal neurological deficits; radiotherapy induces vascular injury, radiation necrosis and gliosis and in patients with longer survival there is also a risk of long-term neurocognitive impairment [12]. Common adverse reactions to temozolomide are mostly limited to the many features of myelotoxicity (anemia, leukopenia, thrombocytopenia) but may also include more unspecific side effects such as nausea, skin rashes and liver toxicity [13-16].

The benefit of the current standard of care, surgical resection followed by radiotherapy and adjuvant chemotherapy, is modest. The Stupp regimen demonstrated a median survival of 14.6 months for treatment with radiotherapy plus temozolomide vs. 12.1 months with radiotherapy alone [7], which is still higher than an expected survival of approximately 7 months with best supportive care only [17]. Although the success of other 'classical' chemotherapies has been limited, the German CeTeG trial demonstrated that the addition of lomustine (CCNU) is beneficial in terms of overall survival in MGMT methylated patients [18]. Other approaches addressing classical cellular signaling pathways (epidermal growth factor receptor: EGFR; fibroblast growth factor receptor: FGFR; tyrosine-protein kinase c-Met: MET; platelet-derived growth factor receptor: PDGFR; phosphoinositide-3-kinase/protein kinase $\mathrm{B} /$ mammalian target of rapamycin: $\mathrm{PI} 3 \mathrm{~K} / \mathrm{AKT} / \mathrm{mTOR}$; mitogen-activated protein kinase: MAPK) have failed for various reasons such as weak penetration of the blood brain barrier [19] or bypasses (e.g., resistance to EGFR therapy via insulin-like growth factor receptor (IGFR)-I signaling) and downregulation of pathways [20,21].

Almost all GB recur (mostly local) after first line treatment and, to date, no standard of care has been established for treating recurrent GB. Commonly applied treatment options are re-surgery (if applicable), re-irradiation, chemotherapy with CCNU or therapy with the angiogenesis inhibitor bevacizumab [22]. Almost all salvage options may be considered as palliative: (i) surgery may not tackle the complete extent of the (mostly dispersed) tumor, (ii) EBRT cannot be applied in the same intensity as in the first line due to the limited tolerance of brain tissue towards radiation and (iii) chemotherapy with temozolomide or CCNU is rendered ineffective by the repair enzyme MGMT.

\section{Tumor Environment and Immunosuppression in the Brain}

It has been controversially discussed for decades if and how the central nervous system (CNS) could be a subject of active immunosurveillance and vigorous immune responses [23]. However, the recent finding that $\mathrm{T}$ cells primed by antigen presenting cells in cervical lymph nodes could reach the brain via connecting lymphatic vessels [24] suggests that although the CNS is clearly an immunologically distinct site, its immune microenvironment offers opportunities to implement immunotherapy for brain tumors [25]. Nevertheless, GB is considered as a poorly immunogenic [26], "cold" tumor with only few tumor-infiltrating lymphocytes (TILs) that frequently express markers of exhaustion $[27,28]$. Furthermore, GB could suppress TIL functions through increased concentrations of extracellular potassium typical for hypoxic tumor areas [29]. In contrast, brain tumors were found to 
be infiltrated by large numbers of myeloid cells such as microglia, macrophages, and myeloid-derived suppressor cells (MDSCs) [30].

It has been demonstrated that MDSCs play a critical role in the development of an immunosuppressive tumor microenvironment [31-33] (Figure 1). This extremely heterogeneous population of myeloid cells was found to efficiently inhibit T-cell mediated anti-tumor reactivity through various mechanisms [31,32,34]. In mice, MDSCs express Gr1 and CD11b surface molecules and consist of two major subsets: polymorphonuclear $\mathrm{CD}_{11 \mathrm{~b}}{ }^{+} \mathrm{Ly} 6 \mathrm{G}^{+} \mathrm{Ly} 6 \mathrm{C}^{\mathrm{lo} /-}$ (PMN-MDSCs) and monocytic CD11b+ $\mathrm{Ly}_{6} \mathrm{G}^{-} \mathrm{Ly} 6 \mathrm{C}^{\mathrm{hi}}$ (M-MDSCs) [31,32,35]. In humans, M-MDSCs are defined as $\mathrm{CD} 11 \mathrm{~b}^{+} \mathrm{CD} 14^{+} \mathrm{CD} 15^{-} \mathrm{HLA}-\mathrm{DR}{ }^{\text {low } /-}$ cells. Human PMN-MDSCs are characterized as

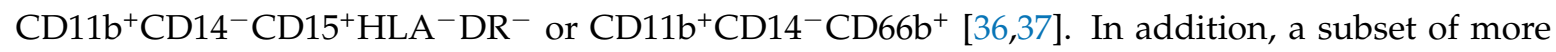
immature human MDSCs characterized as Lin $^{-}$(including CD3, CD14, CD15, CD19, CD56) HLA-DR-CD33 ${ }^{+}$cells were defined as early-stage MDSCs (eMDSCs) [35]. Recently, a lectin-type oxidized LDL receptor-1 (LOX-1) has been proposed as a new marker for human PMN-MDSCs to distinguish them from neutrophils [38].

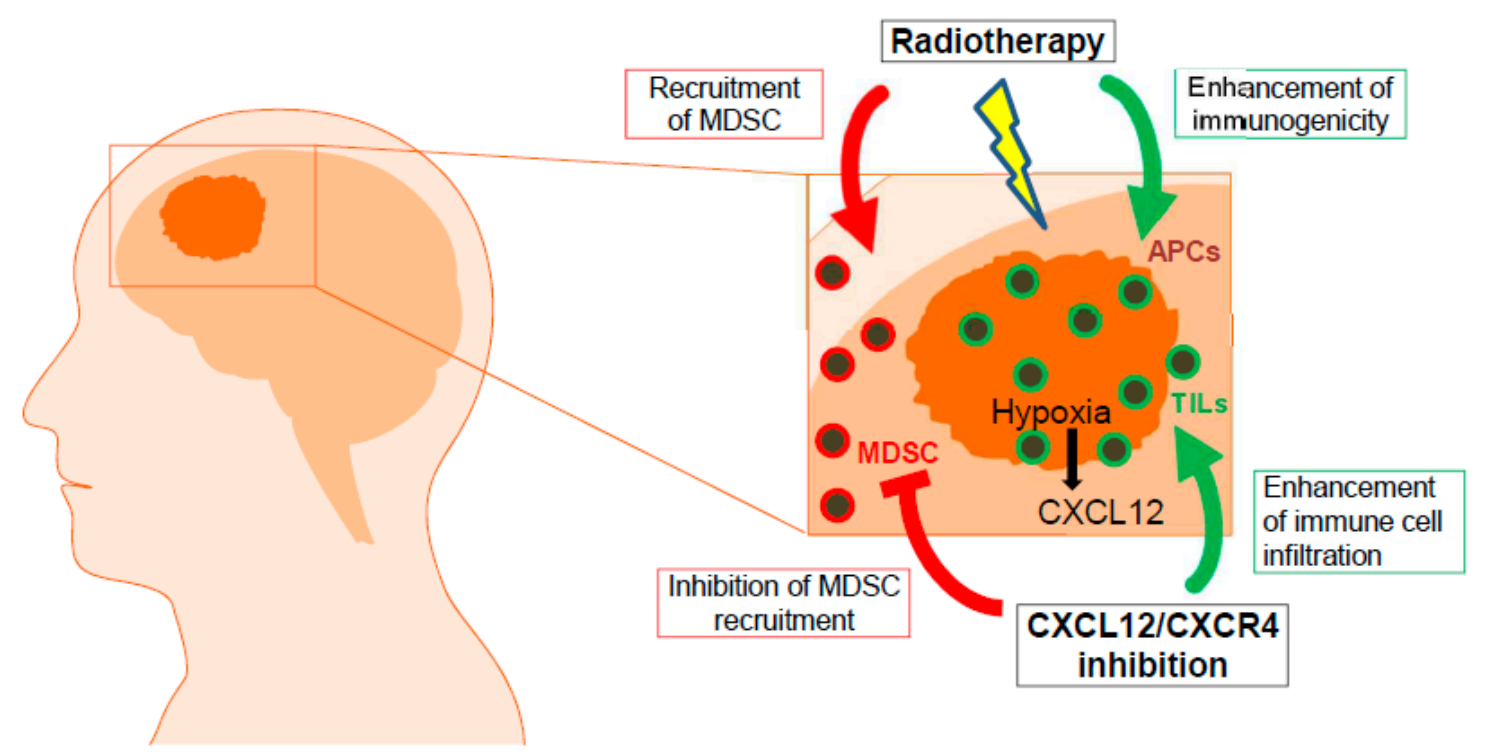

Figure 1. Components of the glioblastoma tumor microenvironment. APC: antigen-presenting cells; MDSC: myeloid-derived suppressor cells; TIL: tumor-infiltrating lymphocytes; CXCL12: C-X-C chemokine ligand 12; CXCR4: C-X-C chemokine receptor 4.

MDSCs derive from bone marrow hematopoietic precursors due to the altering of myelopoiesis induced by chronic inflammatory mediators such as granulocyte-macrophage colony-stimulating factor (GM-CSF), granulocyte colony-stimulating factor (G-CSF), macrophage colony-stimulating factor (M-CSF), stem cell factor (SCF), Vascular Endothelial Growth Factor (VEGF), Interleukin (IL) 6 and $1 \beta[31,32,37,39]$. The signaling mainly involves the signal transducer and activator of transcription 3 (STAT3), preventing MDSC differentiation and promoting their proliferation [40,41]. However, the induction of MDSC activity in tumor lesions is provided by pro-inflammatory molecules such as interferon (IFN)- $\gamma$, IL-1 $\beta$, IL-4, Tumor necrosis factor (TNF)- $\alpha$, toll-like receptor (TLR) ligands, prostaglandin (PGE) E2 and is mediated by STAT1, STAT6 and nuclear factor (NF)- $\mathrm{kB}$ transcription factors [31,40,42].

The migration of MDSCs into the tumor microenvironment is mediated by chemokines produced by tumor and host cells. It has been reported that the trafficking of M-MDSCs occurred via an interaction between chemokine (C-C motif) ligand CCL2 and its receptors CCR2, CCR4, and CCR5 [43]. Moreover, the targeting of CCL2/CCR2 axis with antibodies carlumab showed a modest activity as a single-agent therapeutic in patients with metastatic, castration-resistant prostate cancer [44]. On the other hand, the enhanced production of C-X-C motif receptor (CXCR) 2 ligands supported 
the migration of PMN-MDSCs to the tumor site [45]. Previous publications have indicated that CCL5 supported the tumor growth, invasion, and angiogenesis, as well as immune cell recruitment to the tumor microenvironment via the interaction with CCR5 [46].

In patients with glioblastoma, the frequency of circulating M-MDSCs and PMN-MDSCs was increased as compared to healthy donors [47]. In addition, most of tumor infiltrating MDSC represented PMN-MDSC characterized as $\mathrm{CD}^{+} 5^{+} \mathrm{HLA}^{-} \mathrm{DR}^{-}$cells [47]. Another study revealed that that glioblastoma patients displayed higher frequencies of circulating MDSC than age-matched healthy donors and patients with other tumor entities [48]. Interestingly, the majority of these cells were $\mathrm{CD} 15^{+}$CD14 ${ }^{-}$PMN-MDSCs. Analyzing a cohort of 52 glioblastoma patients, it was reported a strong accumulation of both PMN- and M-MDSC as compared healthy donors [49]. Importantly, reduced MDSC frequency in the peripheral blood of newly diagnosed glioblastoma was found to be associated with their extended survival, providing a basis for developing strategies to target MDSC in glioblastoma [50].

\section{The Glioblastoma Microenvironment Switches from "Angiogenesis" to "Vasculogenesis"}

A hallmark of glioblastoma is an abnormal and dysfunctional vasculature which in combination with the glycolytic environment leads to hypoxia [51]. It is now considered that severely hypoxic zones contribute to invasion by causing so called 'pseudopalisades' of cells to migrate away from the central hypoxia $[52,53]$. Radiotherapy (RT) is one of the key treatment modalities of glioblastoma and has been reported to cause blood vessel damage that may lead to additional tumor cell kill with sufficiently high radiation doses per fraction [54]. Although radiation-induced loss of blood vessels is widely considered a positive effect of RT, it initiates a chain of events that counteract tumor cell killing [55]. Depletion of microvasculature results in weakly perfused or non-perfused areas in which hypoxia-surviving cells respond with overexpression of the otherwise constitutively but only moderately expressed transcription factor hypoxia induced factor 1 alpha (HIF-1 $\alpha$ ). HIF-1 $\alpha$ then induces expression of a wide variety of genes such as VEGF and angiopoietin 2 (ANGPT2), which in turn counteract hypoxia by promoting angiogenesis [56,57]. Besides these rather "directly" acting factors, HIF- $1 \alpha$ also induces overexpression of CXC-motive chemokine ligand 12 (CXCL12), formerly known as stromal-cell derived factor 1 (SDF-1). CXCL12 in turn attracts hematopoietic progenitor cells that carry the chemokine (C-X-C motif) receptor 4 (CXCR4; also known as CD184 or fusin).

\section{The CXCL12/CXCR4/ACKR3 Axis in Inflammation and Vasculogenesis}

Overexpression of CXCL12 and CXCR4 is associated with higher grade and poor prognosis of GBM $[58,59]$. A potentially important aspect of targeting CXCL12 is its ability to form a heterodimer with high mobility group B1 (HMGB1), a non-histone nuclear protein which acts as a damage associated molecular pattern (DAMP) molecule [60]. Thus, HMGB1 and other DAMP molecules (calreticulin, ATP, dsDNA) are released by damaged cells after irradiation with doses high enough to initiate an inflammatory response [61]. Heterodimerization of CXCL12 with HMGB1 is necessary for attracting monocytes to injured tissue, and migration of mouse embryo fibroblasts and leukocytes towards HMGB1 could be blocked by the CXCR4 inhibitor plerixafor (formerly known as AMD 3100) [62,63]. The redox state of HMGB1 determines which signal pathways are activated; thus, the reduced all-thiol form binds to CXCL12 in a heterocomplex which is more efficient in attracting lymphocytes than CXCL12 alone [60,64]. In relation to tumors, CXCR4 is present on a number of immune suppressor cells, including regulatory T cells (Treg) and myeloid-derived suppressor cells (MDSCs) [65].

The production of CXCL12 can be induced by prostaglandin E2 resulting in a strong enrichment of MDSCs in ovarian and gastric cancer microenvironment [66]. Furthermore, CXCL12-CXCR4 signaling pathways are also reported to be involved in MDSC trafficking in a breast tumor mouse model [67]. Moreover, CXCL12 produced by cancer associated fibroblasts can recruit MDSCs to the tumor microenvironment to exert tumor-promoting effects in mouse model of hepatic carcinoma [68] and estrogen receptor-negative breast cancer [69]. Therefore, CXCL12/CXCR4 interaction could be 
considered as an important driving force of MDSC recruitment into the tumor microenvironment. Thus, future immune-based strategies may be focused on combinations of different immune checkpoint inhibitors with substances targeting CXCL12/CXCR4 and reversal of local immunosuppression in the microenvironment, converting a 'cold' tumor into a 'hot' tumor [25,70].

Significantly, expression of CXCL12 and CXCR4 was observed in hypoxic regions but not in regions with proliferating cells [71-73]. Hypoxia induces expression of HIF- $1 \alpha$ which activates transcription of VEGF and upregulates CXCL12, leading to recruitment of CXCR4 ${ }^{+}$bone marrow cells and neovasculogenesis $[74,75]$. A major component of these bone marrow-derived cells for neovasculogenesis is monocytes, which in the tumors differentiate into tumor-associated macrophages (TAMs). These TAMs promote tumor invasiveness, immune suppression and formation of new blood vessels [76,77].

Irradiation of GBM leads to loss of vasculature and increasing hypoxia [78,79] (Figure 2). Doses of 5-15 Gy stimulate vasculogenesis by upregulating CXCL12, in part via stimulation of HIF-1 $\alpha[74,75]$. Since recurrence of glioblastoma after radiotherapy relies on vasculogenesis, targeting CXCL12/CXCR4 was suggested as a novel therapeutic rationale in combination with radiotherapy in these tumors $[79,80]$. In a mouse GBM model, inhibition of CXCR4 with plerixafor (formerly known as AMD3100) prevented recruitment of bone marrow-derived cells (mainly CD11 ${ }^{+}$cells), which together with irradiation (5x2Gy or 1x15Gy) prevented tumor recurrence [78], suggesting that these CD11 $\mathrm{b}^{+}$ monocytes or their differentiated progeny, TAMs, supply signals for the formation of new vessels. This was corroborated by the ability of the CXCL12 antagonist NOX-A12, to control autochthonous brain tumors in rats. NOX-A12 is a so-called 'Spiegelmer', a class of synthetic L-ribonucleic acids that are designed to bind to specific targets conceptually similar to antibodies [81]. In this rat brain tumor model, which is extremely resistant to anticancer therapy, and which results in tumors with a genetic diversity and aggressiveness comparable to human brain tumors [82], NOX-A12 in combination with 20 Gy single dose irradiation significantly reduced tumor burden and prolonged rat survival even if the rats were irradiated when the tumors were already established [83]. In another model, NOX-A12 also enhanced the effect of the anti-VEGF antibody bevacizumab [84].

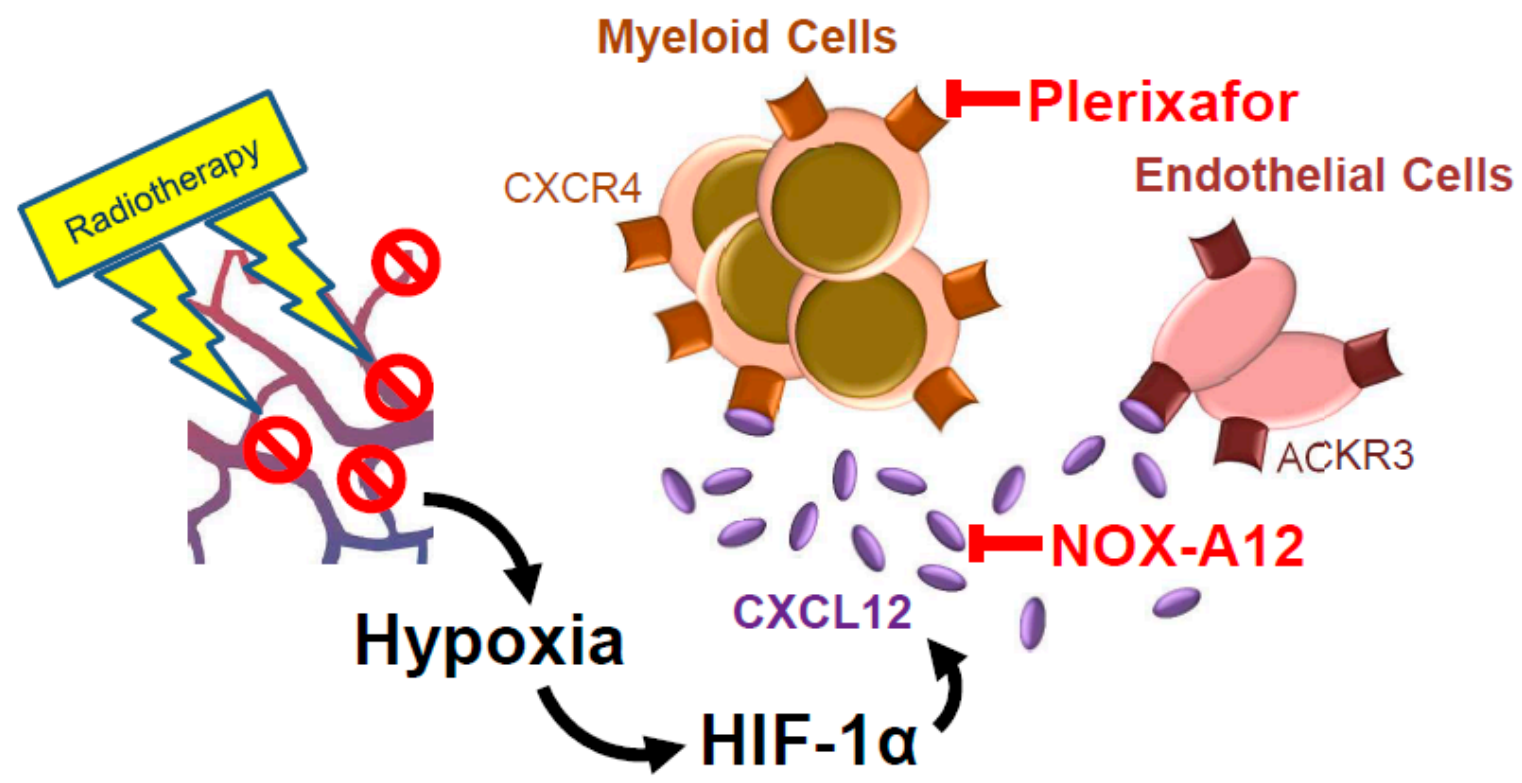

Figure 2. Radiotherapy increases hypoxia in glioblastoma by damaging the tumor vasculature. This leads to upregulation of CXCL12 via HIF-1 $\alpha$ (hypoxia-induced factor-1 $\alpha$ ). Plerixafor (AMD3100) is representative of a number of different types of CXCR4 inhibitors. NOX-A12 binds to and inhibits CXCL12 directly. 
CXCL12 was also shown to recruit endothelial progenitor cells from the bone marrow to the tumor microenvironment where they form a new, functional vessel architecture that re-nourishes the tumor and propagates its regrowth [55]. Although some studies have reported that such ACKR3+ endothelial progenitor cells are supplied by the bone marrow, evidence from other studies point towards recruitment of circulating progenitor cells [79]. In fact, it could be shown experimentally that all components of the CXCL12/CXCR4/ACKR3 axis are relevant for recurrence of glioblastoma after radiotherapy, as inhibition of ACKR3 alone in combination with irradiation was also effective in preclinical models [85]. Furthermore, CXCL12-dependent vascularization turned out to be the most prominent bypass mechanism of VEGF-targeted therapy [86].

\section{Function of the CXCL12-CXCR4 Axis in Brain and Glioblastoma}

CXCL12 belongs to the evolutionary conserved CXC chemokine family expressed especially in the immune system, central nervous systems, and vasculature, of higher vertebrates [87]. CXCL12 has multiple functions that are essential during development and is perinatally lethal in knockout mice. Embryos show defective B-cell lymphopoiesis and myelopoiesis, abnormal neuron migration, and lacking or defective vasculature in kidneys, heart, and skin [88-93]. CXCL12 is expressed by different cell types including stromal cells in the bone marrow, glial and neuronal cells in the nervous system, and endothelial cells in various organs (reviewed in reference [87]). Six different splice variants in humans (CXCL12 $\alpha$ to $\phi$ ) are transcriptionally regulated in different cell types. The functions of their products are further regulated by posttranslational modification, including proteolytic truncation, citrullination of Arg residues, and nitration of Tyr residues (reviewed in reference [94]).

CXCL12 is the only chemokine ligand binding to CXCR4, a heptahelical G-protein coupled receptor (GPCR) that is expressed on circulating leukocytes, hematopoietic progenitor and stem cells, as well as on endothelial, stromal and epithelial cells in various tissues [95]. Dissociation of G-protein subunits leads to intracellular signal transduction through MAP Kinase, PI3K/AKT, and phospholipase $C$ pathways, inhibits cAMP signaling, and activates $\mathrm{Ca}^{2+}$ and $\mathrm{K}^{+}$ion channels $[75,87]$. A further receptor for CXCL12 is atypical chemokine receptor (ACKR) 3 (formerly known as CXCR7). ACKRs are heptahelical membrane receptors that do not activate G-protein and are expressed mainly on non-leukocyte cell types, including vascular endothelial cells [96]. ACKR3 has a higher affinity for CXCL12 than CXCR4 and can act as a scavenger by internalization. However, it is also able to signal to MAP Kinase and p38 via $\beta$-arrestin $[87,94]$ and has been reported to activate MAP Kinase via $G$ protein in astrocytes and glioma cells [97]. In addition to membrane receptors, CXCL12 can bind to glycosaminoglycans (GAG) such as heparin sulfate found in the extracellular matrix and heparin secreted by mast cells, which is important for setting up chemokine gradients required for directed cell migration [94,98]. A schematic overview of the CXCL12/CXCR4/ACKR3 signaling cascade is shown in Figure 3.

Homo-dimerization of CXCR4 and hetero-dimerization of CXCR4 with ACKR3 or other chemokine receptors determines the choice between multiple pathways leading to proliferation, migration, cell adhesion, or survival [75]. Thus, CXCL12 signaling via CXCR4 versus ACKR3 was shown to activate different transcriptional profiles, including two miRNAs [99].

An important function of the CXCL12/CXCR4/ACKR3 axis is regulation of migration and homing of stem and progenitor cells to their niches $[75,100,101]$. Thus, it regulates stem cells in the bone marrow as well as in the peripheral and central nervous system, and attracts lymphocytes and monocytes expressing the CXCR4 receptor [75]. In the brain, adult neural stem cells are found in vascular niches, and mesenchymal stem cells with potential for differentiating into astrocytes have been found in the perivascular niche [102]. Similarly, glioblastoma stem cells are found in perivascular niches [103] which have recently been reported to be hypoxic periarteriolar rather than pericapillary, and in which endothelial cells and smooth muscle cells provide signals required for maintenance [104]. CXCL12 is expressed by microvascular endothelial cells and stimulated proliferation of GBM progenitor cells but not differentiated tumor cells via CXCR4, whereas ACKR3 was not involved $[105,106]$. Furthermore, 
a CXCL12 gradient stimulates migration of GBM cells [107] by $\mathrm{Ca}^{2+}$-dependent activation of BK (Big-Potassium) $\mathrm{K}^{+}$channels [108]. Notably, CXCL12-CXCR4 interactions target GBM stem cells to endothelial cells in the perivascular niche where they may be induced to differentiate into pericytes by transforming growth factor (TGF)- $\beta 1$ [109].

Recent evidence supports the hypothesis human glioblastoma arises from neural stem cells in the subventricular zone (SVZ) [110] though, in a xenograft model, GBM cells have been found to migrate from the tumor to SVZ which was reported to constitute a CXCL12-dependent radioresistant niche [111]. However, the evidence for radioresistance is open to alternative interpretations and no direct evidence for an effect on cell survival was presented. Nevertheless, GBM stem cells are generally considered to show radioresistance mediated by intracellular cell signaling pathways and microenvironmental factors [112].

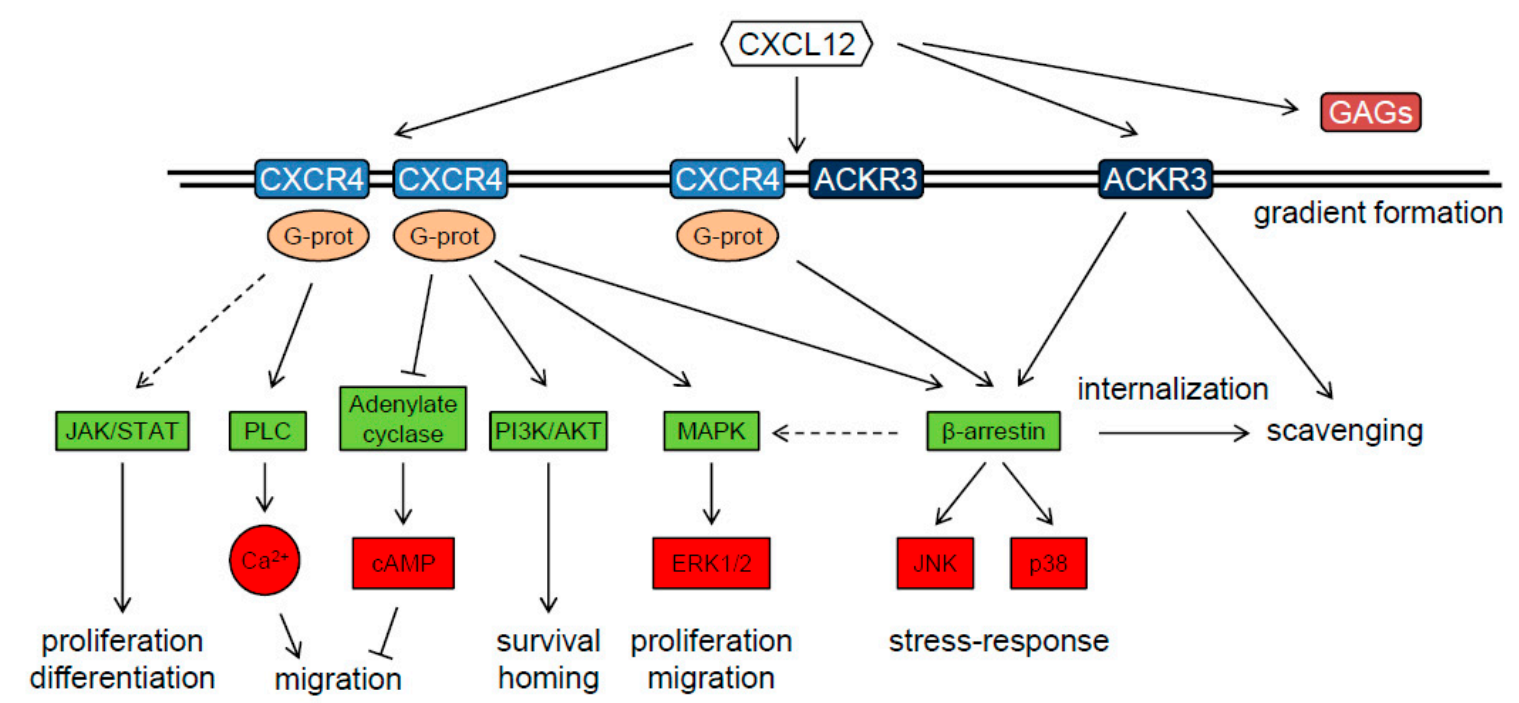

Figure 3. Schematic overview of the CXCL12-CXCR4-ACKR3 signaling cascade. Intermediate kinases have been omitted (for a detailed description, see reviews by Würth et al. [75] and Janssen et al. [94]). cAMP: cyclic adenosine-3',5'-monophosphate; ERK1/2: extracellular signal-regulated kinase 1/2; GAG: glycosaminoglycans (heparin, heparan sulfate); G-prot: G-proteins; JAK/STAT: Janus kinase/signal transducers and activators of transcription; JNK: c-Jun N-terminal kinase; MAPK: mitogen-activated protein kinase; PI3K/AKT: phosphoinositide-3-kinase/Protein kinase B; PLC: phospholipase C.

\section{CXCL12 in Extracranial Tumors}

The CXCL12/CXCR4/ACKR3 axis is not only implicated in GB, but also in extracranial tumors and is involved in tumor progression, angiogenesis, metastasis, and survival as well as contributing to immunosuppressive networks within the tumor microenvironment [113]. In hematological malignancies, the cross-talk among lymphoma, myeloma and leukemia cells and their microenvironments is mediated via CXCL12 and its receptors [114] and interference with CXCL12 signaling not only directly inhibits leukemic cell proliferation, but also mobilizes leukemic-lymphoma cells from their niches improving the efficacy of conventional treatments [115].

In solid malignancies, CXCL12 was shown to synergize with vascular endothelial growth factor (VEGF) to promote tumor angiogenesis [116]. CXCL12 also promotes tumor cell proliferation and survival [117] as well as invasion and metastasis via CXCR4 [118,119]. Interestingly, CXCR4+ tumor cells may have stem-like properties, a high metastatic potential, and show radiation resistance [120,121]. Some tumors also express ACKR3, which can promote adhesion, invasion, survival and growth $[122,123]$.

Targeting the CXCL12/CXCR4 axis attenuated non-small cell lung cancer growth and augmented the effects of chemotherapy and radiotherapy [124]. In pancreatic cancer, inhibition of the CXCL12/CXCR4 axis arrested cell growth and abrogated gemcitabine resistance [125] as well as 
reduced tumor growth in animal models by blocking CXCR4-dependent mast cell migration [126]. CXCL12/CXCR4 axis blockade in combination with sorafenib treatment was reported to inhibit hepatocellular cancer growth [127]. Blocking the CXCR4/CXCL12 axis also inhibited tumor growth and metastasis formation in breast cancer models $[128,129]$. In models of prostate cancer, inhibition of CXCR4-dependent vascularization delayed tumor growth [130]. In addition, inhibition of CXCL12/CXCR4 signaling by antibodies, peptide analogues, or small molecules has been found to reduce metastatic burden in various orthotopic and metastatic mouse xenograft models [131-133].

Recently, it was reported that $\mathrm{T}$ cells may be excluded from cancer cell nests by high CXCL12 levels. Consequently, blocking the CXCL12/CXCR4 axis improved immuno-oncological approaches such as checkpoint inhibition in models of pancreatic cancer [134] and hepatocellular cancer [135]. Clinically, patients with cervical cancer treated with standard-of-care radio-chemotherapy and the CXCR4 inhibitor plerixafor showed improved primary tumor response and reduced metastases [136].

\section{Current CXCL12/CXCR4/ACKR3 Inhibitors}

A number of antagonists and inhibitors targeting the CXCL12/CXCR4/ACKR3 axis are being developed in cancer indications, mostly in non-brain tumor related cancers and not in combination with radiotherapy (Table 1). Whereas three agents-plerixafor, NOX-A12 and USL311-have been or are reported to be tested in glioblastoma, only the first two are currently explored in combination with radiotherapy, thus targeting the angiogenic-vasculogenic 'switch' induced by radiotherapy. Plerixafor is a bicyclam molecule that antagonizes the CXCR4 receptor. It rapidly and reversibly mobilizes hematopoietic stem cells into the peripheral circulation and was first approved in combination with granulocyte-colony stimulating factor (G-CSF) to mobilize hematopoietic stem cells to the peripheral blood for collection and subsequent autologous transplantation in patients with hematological malignancies.

This approach is currently being tested in a Phase $1 / 2$ study in adult patients with newly diagnosed glioblastoma assessing the impact of CXCR4 blockade with plerixafor combined with radiotherapy and temozolomide (NCT01977677). Interim data presented at ASCO 2018, with 29 patients enrolled, validate the concept of targeting the axis. This study showed that inhibition of the CXCL12/CXCR4 axis (i) is safe in brain tumor patients, (ii) leads to improved local control, (iii) may improve overall survival with an estimated median OS of 20.7 months, and (iv) shifts the pattern of recurrence towards an out-of-field pattern (58.8\% out-of-field recurrences vs. $10 \%$ in a control group) [137]. This study therefore validates preclinical data by demonstrating that inhibition of the CXCL12/CXCR4 pathway improves local control of GBM following radiotherapy $[78,83]$. Another study with plerixafor was performed in recurrent high-grade glioma (HGG) patients in combination with VEGF inhibition but without concomitant radiotherapy. This approach tested whether blocking CXCR4 could break the resistance of the tumor to anti-angiogenic therapy. However, while confirming good safety and tolerability of the combination in these patients, the effect on the clinical outcome of these particularly hard-to-treat patients was limited [138].

Targeting the ligand, CXCL12, rather than its receptor, CXCR4, NOX-A12 is another inhibitor of the axis that is to be tested in brain tumors in combination with radiotherapy. The compound was previously tested in two phase I studies in healthy volunteers and two phase Ila studies, one in multiple myeloma patients [139], and one in patients with chronic lymphocytic leukemia. Another phase I/II study in patients with pancreatic and colorectal cancer in combination with PD-1 checkpoint inhibition is ongoing (Keynote-559; NCT03168139). The translational relevance of the preclinical data generated with NOX-A12 described earlier [83] is supported by clinical correlative studies showing that elevated expression of CXCL12 and its receptors, CXCR4 and ACKR3, is associated with higher tumor grade and invasion as well as decreased apoptosis in glioblastoma [140,141]. 
Table 1. Antagonists of the CXCL12/CXCR4/ACKR3 axis currently in clinical development for cancer.

\begin{tabular}{|c|c|c|c|c|}
\hline Compound & Company & $\begin{array}{c}\text { Type of } \\
\text { Molecule }\end{array}$ & Target & Indications and Study Pase \\
\hline $\begin{array}{l}\text { Mozobil }^{\circledR} \\
\text { (plerixafor, } \\
\text { AMD3100) }\end{array}$ & Sanofi-Genzyme & $\begin{array}{c}\text { Small } \\
\text { molecule }\end{array}$ & CXCR4 & $\begin{array}{c}\text { Stem cell mobilization: approved } \\
\text { Multiple myeloma: Phase } 1 / 2 \\
\text { Glioblastoma: Phase } 1 / 2 \\
\text { Advanced solid tumors (pancreas, ovarian, colorectal): Phase } 1 \\
\text { AML/ALL: Phase } 1\end{array}$ \\
\hline BL-8040 & BioLineRx & Peptide & CXCR4 & $\begin{array}{c}\text { Stem cell mobilization: Phase } 3 \\
\text { AML*: Phase } 2 \\
\text { Metastatic pancreatic cancer*: Phase } 2 \\
\text { T-ALL: Phase } 2 \\
\text { Advanced gastric cancer*: Phase } 1 / 2 \\
\text { Metastatic non-small cell lung cancer*: Phase } 1 / 2\end{array}$ \\
\hline $\begin{array}{l}\text { NOX-A12 } \\
\text { Olaptesed pegol }\end{array}$ & $\begin{array}{l}\text { NOXXON } \\
\text { Pharma }\end{array}$ & $\begin{array}{l}\text { L-RNA, } \\
\text { PEGylated }\end{array}$ & CXCL12 & $\begin{array}{l}\text { Metastatic colorectal and pancreatic cancer: Phase } 1 / 2^{*} \\
\text { Glioblastoma: Phase } 1 / 2\end{array}$ \\
\hline $\begin{array}{l}\text { Burixafor } \\
\text { TG-0054 }\end{array}$ & TaiGen & $\begin{array}{c}\text { Small } \\
\text { molecule }\end{array}$ & CXCR4 & Metastatic prostate cancer: Phase 1 \\
\hline LY-2510924 & Eli Lilly & Peptide & CXCR4 & $\begin{array}{c}\text { AML: Phase } 1 \\
\text { Discontinued: } \\
\text { Metastatic clear cell renal cell carcinoma combined with sunitinib } \\
\text { (Phase 2) } \\
\text { Extensive-disease small-cell lung cancer combined with } \\
\text { carboplatin/etoposide (Phase 2) }\end{array}$ \\
\hline $\begin{array}{l}\text { Balixafortide } \\
\text { POL6326 }\end{array}$ & Polyphor & Peptide & CXCR4 & Metastatic breast cancer: Phase 1 \\
\hline $\begin{array}{l}\text { Ulocuplumab } \\
\text { BMS } 936564\end{array}$ & BMS & $\begin{array}{l}\text { Monoclonal } \\
\text { antibody }\end{array}$ & CXCR4 & $\begin{array}{c}\text { Waldenström's macroglobulinemia: Phase } 1 / 2 \\
\text { AML: Phase } 1 / 2 \\
\text { Discontinued: } \\
\text { Advanced solid tumors (pancreatic and lung cancer patients) } \\
\text { combined with nivolumab (Phase } 1 / 2 \text { ) }\end{array}$ \\
\hline X4P-001 & $\begin{array}{c}\text { X4 } \\
\text { Pharmaceuticals }\end{array}$ & $\begin{array}{c}\text { Small } \\
\text { molecule }\end{array}$ & CXCR4 & $\begin{array}{c}\text { Metastatic clear cell renal cell carcinoma* }{ }^{* *} \text { : Phase } 1 / 2 \\
\text { Resectable melanoma*: Phase } 1\end{array}$ \\
\hline USL311 & Proximagen & $\begin{array}{c}\text { Small } \\
\text { molecule }\end{array}$ & CXCR4 & Recurrent glioblastoma: Phase 2 \\
\hline
\end{tabular}

*plus PD-1/PD-L1 inhibitor; **plus axitinib. ALL—acute lymphoblastic leukemia; AML-acute myeloid leukemia; CLL—chronic lymphocytic leukemia; MM—multiple myeloma.

\section{Conclusions}

The CXCL12/CXCR4 axis is a key regulator of the post-radiotherapy microenvironment in glioblastoma. Blocking of CXCL12 or CXCR4 could prevent the influx of tumor associated macrophages and myeloid suppressor cells which mediate re-vascularization and immunosuppression respectively. Initial results from an early clinical trial warrant further investigation of this therapeutic approach in glioblastoma.

Funding: This research was funded in part by the German Research Council (RTG2099 to VU) and the DKFZ-MOST Cooperation in Cancer Research (CA181 to VU).

Conflicts of Interest: F.A.G.: consultant and speaker for Carl Zeiss Meditec AG, NOXXON Pharma, MSD Sharp and Dohme, Roche Pharma AG, AstraZeneca, Bristol-Myers Squibb and Oncare, holds patents related with Carl Zeiss Meditec AG, co-founder and stakeholder of Implacit. Research grants from Guerbet SA, Carl Zeiss Medotec, Elekta AB and NOXXON Pharma. B.L.: none. M.G.: consulting and advisory role to Roche, Novartis, Daiichi Sankyo, Novocure. Travel support received from Medac, Novocure. Honoraria received from Novartis, Merck, Novocure, Medac, Kyowa Kirin, Bayer. U.H.: Consultant and/or speaker for Roche, Medac, Bristol-Myers Squibb, Novocure, Novartis, Daichii-Sankyo, Riemser, Noxxon. F.W.: advisor, consultant and/or speaker for Celgene $\mathrm{GmbH}$, Roche Pharma AG, Eli Lilly and Company, Ipsen Pharma GmbH, receives travel and research grants from Carl Zeiss Meditec AG and Elekta AB, is on the Carl Zeiss Meditec AG speaker's bureau, holds patents related with Carl Zeiss Meditec AG. V.U.: consultant for NOXXON Pharma. Research grants from NOXXON Pharma and Apogenix. J.M.B.: None. C.H.: teaching the radiobiology of low-energy X-rays for Carl Zeiss Meditec AG; co-inventor of patent held by Carl Zeiss Meditec AG. 


\section{References}

1. Agnihotri, S.; Burrell, K.E.; Wolf, A.; Jalali, S.; Hawkins, C.; Rutka, J.T.; Zadeh, G. Glioblastoma, a brief review of history, molecular genetics, animal models and novel therapeutic strategies. Arch. Immunol. Ther. Exp. 2013, 61, 25-41. [CrossRef] [PubMed]

2. Ostrom, Q.T.; Gittleman, H.; Farah, P.; Ondracek, A.; Chen, Y.; Wolinsky, Y.; Stroup, N.E.; Kruchko, C.; Barnholtz-Sloan, J.S. CBTRUS statistical report: Primary brain and central nervous system tumors diagnosed in the United States in 2006-2010. Neuro-Oncology 2013, 15 (Suppl. 2), ii1-ii56. [CrossRef] [PubMed]

3. Behin, A.; Hoang-Xuan, K.; Carpentier, A.F.; Delattre, J.Y. Primary brain tumours in adults. Lancet 2003, 361, 323-331. [CrossRef]

4. Correa, D.D. Cognitive functions in brain tumor patients. Hematol. Oncol. Clin. N. Am. 2006, 20, $1363-1376$. [CrossRef] [PubMed]

5. Kreth, F.W.; Thon, N.; Simon, M.; Westphal, M.; Schackert, G.; Nikkhah, G.; Hentschel, B.; Reifenberger, G.; Pietsch, T.; Weller, M.; et al. Gross total but not incomplete resection of glioblastoma prolongs survival in the era of radiochemotherapy. Ann. Oncol. 2013, 24, 3117-3123. [CrossRef] [PubMed]

6. Gittleman, H.; Lim, D.; Kattan, M.W.; Chakravarti, A.; Gilbert, M.R.; Lassman, A.B.; Lo, S.S.; Machtay, M.; Sloan, A.E.; Sulman, E.P.; et al. An independently validated nomogram for individualized estimation of survival among patients with newly diagnosed glioblastoma: NRG Oncology RTOG 0525 and 0825. Neuro-Oncology 2017, 19, 669-677. [CrossRef] [PubMed]

7. Stupp, R.; Mason, W.P.; van den Bent, M.J.; Weller, M.; Fisher, B.; Taphoorn, M.J.; Belanger, K.; Brandes, A.A.; Marosi, C.; Bogdahn, U.; et al. Radiotherapy plus concomitant and adjuvant temozolomide for glioblastoma. N. Engl. J. Med. 2005, 352, 987-996. [CrossRef] [PubMed]

8. Malmstrom, A.; Gronberg, B.H.; Marosi, C.; Stupp, R.; Frappaz, D.; Schultz, H.; Abacioglu, U.; Tavelin, B.; Lhermitte, B.; Hegi, M.E.; et al. Temozolomide versus standard 6-week radiotherapy versus hypofractionated radiotherapy in patients older than 60 years with glioblastoma: The Nordic randomised, phase 3 trial. Lancet Oncol. 2012, 13, 916-926. [CrossRef]

9. Wick, W.; Platten, M.; Meisner, C.; Felsberg, J.; Tabatabai, G.; Simon, M.; Nikkhah, G.; Papsdorf, K.; Steinbach, J.P.; Sabel, M.; et al. Temozolomide chemotherapy alone versus radiotherapy alone for malignant astrocytoma in the elderly: The NOA-08 randomised, phase 3 trial. Lancet Oncol. 2012, 13, 707-715. [CrossRef]

10. Sulman, E.P.; Ismaila, N.; Armstrong, T.S.; Tsien, C.; Batchelor, T.T.; Cloughesy, T.; Galanis, E.; Gilbert, M.; Gondi, V.; Lovely, M.; et al. Radiation Therapy for Glioblastoma: American Society of Clinical Oncology Clinical Practice Guideline Endorsement of the American Society for Radiation Oncology Guideline. J. Clin. Oncol. 2017, 35, 361-369. [CrossRef] [PubMed]

11. Stupp, R.; Taillibert, S.; Kanner, A.; Read, W.; Steinberg, D.; Lhermitte, B.; Toms, S.; Idbaih, A.; Ahluwalia, M.S.; Fink, K.; et al. Effect of Tumor-Treating Fields Plus Maintenance Temozolomide vs. Maintenance Temozolomide Alone on Survival in Patients with Glioblastoma: A Randomized Clinical Trial. JAMA 2017, 318, 2306-2316. [CrossRef] [PubMed]

12. Klein, M. Neurocognitive functioning in adult WHO grade II gliomas: Impact of old and new treatment modalities. Neuro-Oncology 2012, 14 (Suppl. 4), iv17-iv24. [CrossRef] [PubMed]

13. Stupp, R.; Hegi, M.E.; Mason, W.P.; van den Bent, M.J.; Taphoorn, M.J.; Janzer, R.C.; Ludwin, S.K.; Allgeier, A.; Fisher, B.; Belanger, K.; et al. Effects of radiotherapy with concomitant and adjuvant temozolomide versus radiotherapy alone on survival in glioblastoma in a randomised phase III study: 5-year analysis of the EORTC-NCIC trial. Lancet Oncol. 2009, 10, 459-466. [CrossRef]

14. Bae, S.H.; Park, M.J.; Lee, M.M.; Kim, T.M.; Lee, S.H.; Cho, S.Y.; Kim, Y.H.; Kim, Y.J.; Park, C.K.; Kim, C.Y. Toxicity profile of temozolomide in the treatment of 300 malignant glioma patients in Korea. J. Korean Med. Sci. 2014, 29, 980-984. [CrossRef] [PubMed]

15. Sengupta, S.; Marrinan, J.; Frishman, C.; Sampath, P. Impact of temozolomide on immune response during malignant glioma chemotherapy. Clin. Dev. Immunol. 2012, 2012, 831090. [CrossRef] [PubMed]

16. Hilverda, K.; Bosma, I.; Heimans, J.J.; Postma, T.J.; Peter Vandertop, W.; Slotman, B.J.; Buter, J.; Reijneveld, J.C.; Klein, M. Cognitive functioning in glioblastoma patients during radiotherapy and temozolomide treatment: Initial findings. J. Neurooncol. 2010, 97, 89-94. [CrossRef] [PubMed] 
17. Keime-Guibert, F.; Chinot, O.; Taillandier, L.; Cartalat-Carel, S.; Frenay, M.; Kantor, G.; Guillamo, J.S.; Jadaud, E.; Colin, P.; Bondiau, P.Y.; et al. Radiotherapy for glioblastoma in the elderly. N. Engl. J. Med. 2007, 356, 1527-1535. [CrossRef] [PubMed]

18. Herrlinger, U.; Tzaridis, T.; Mack, F.; Steinbach, J.; Schlegel, U.; Sabel, M.; Hau, P.; Kortman, R.-D.; Krex, D.; Grauer, O.; et al. ACTR-58. Phase III trial of CCNU/temozolomide (TMZ) combination therapy vs. standard TMZ therapy for newly diagnosed MGMT-methylated glioblastoma patients: THE CeTeg/NOA-09 trial. Neuro-Oncology 2017, 19, vi13-vi14. [CrossRef]

19. Mellinghoff, I.K.; Lassman, A.B.; Wen, P.Y. Signal transduction inhibitors and antiangiogenic therapies for malignant glioma. Glia 2011, 59, 1205-1212. [CrossRef] [PubMed]

20. Wang, M.; Maier, P.; Wenz, F.; Giordano, F.A.; Herskind, C. Mitogenic signalling in the absence of epidermal growth factor receptor activation in a human glioblastoma cell line. J. Neurooncol. 2013, 115, 323-331. [CrossRef] [PubMed]

21. Chakravarti, A.; Loeffler, J.S.; Dyson, N.J. Insulin-like growth factor receptor I mediates resistance to anti-epidermal growth factor receptor therapy in primary human glioblastoma cells through continued activation of phosphoinositide 3-kinase signaling. Cancer Res. 2002, 62, 200-207. [PubMed]

22. Wick, W.; Gorlia, T.; Bendszus, M.; Taphoorn, M.; Sahm, F.; Harting, I.; Brandes, A.A.; Taal, W.; Domont, J.; Idbaih, A.; et al. Lomustine and Bevacizumab in Progressive Glioblastoma. N. Engl. J. Med. 2017, 377, 1954-1963. [CrossRef] [PubMed]

23. Waksman, B.H.; Adams, R.D. Allergic neuritis: An experimental disease of rabbits induced by the injection of peripheral nervous tissue and adjuvants. J. Exp. Med. 1955, 102, 213-236. [CrossRef] [PubMed]

24. Louveau, A.; Smirnov, I.; Keyes, T.J.; Eccles, J.D.; Rouhani, S.J.; Peske, J.D.; Derecki, N.C.; Castle, D.; Mandell, J.W.; Lee, K.S.; et al. Structural and functional features of central nervous system lymphatic vessels. Nature 2015, 523, 337-341. [CrossRef] [PubMed]

25. Lim, M.; Xia, Y.; Bettegowda, C.; Weller, M. Current state of immunotherapy for glioblastoma. Nat. Rev. Clin. Oncol. 2018, 15, 422-442. [CrossRef] [PubMed]

26. Patel, M.A.; Pardoll, D.M. Concepts of immunotherapy for glioma. J. Neurooncol. 2015, 123, $323-330$. [CrossRef] [PubMed]

27. Hao, C.; Parney, I.F.; Roa, W.H.; Turner, J.; Petruk, K.C.; Ramsay, D.A. Cytokine and cytokine receptor mRNA expression in human glioblastomas: Evidence of Th1, Th2 and Th3 cytokine dysregulation. Acta Neuropathol. 2002, 103, 171-178. [CrossRef] [PubMed]

28. Wherry, E.J. T cell exhaustion. Nat. Immunol. 2011, 12, 492-499. [CrossRef] [PubMed]

29. Eil, R.; Vodnala, S.K.; Clever, D.; Klebanoff, C.A.; Sukumar, M.; Pan, J.H.; Palmer, D.C.; Gros, A.; Yamamoto, T.N.; Patel, S.J.; et al. Ionic immune suppression within the tumour microenvironment limits T cell effector function. Nature 2016, 537, 539-543. [CrossRef] [PubMed]

30. Li, B.; Severson, E.; Pignon, J.C.; Zhao, H.; Li, T.; Novak, J.; Jiang, P.; Shen, H.; Aster, J.C.; Rodig, S.; et al. Comprehensive analyses of tumor immunity: Implications for cancer immunotherapy. Genome Biol. 2016, 17, 174. [CrossRef] [PubMed]

31. Gabrilovich, D.I.; Ostrand-Rosenberg, S.; Bronte, V. Coordinated regulation of myeloid cells by tumours. Nat. Rev. Immunol. 2012, 12, 253-268. [CrossRef] [PubMed]

32. Parker, K.H.; Beury, D.W.; Ostrand-Rosenberg, S. Myeloid-Derived Suppressor Cells: Critical Cells Driving Immune Suppression in the Tumor Microenvironment. Adv. Cancer Res. 2015, 128, 95-139. [CrossRef] [PubMed]

33. Veglia, F.; Perego, M.; Gabrilovich, D. Myeloid-derived suppressor cells coming of age. Nat. Immunol. 2018, 19, 108-119. [CrossRef] [PubMed]

34. Meirow, Y.; Kanterman, J.; Baniyash, M. Paving the Road to Tumor Development and Spreading: Myeloid-Derived Suppressor Cells are Ruling the Fate. Front. Immunol. 2015, 6, 523. [CrossRef] [PubMed]

35. Bronte, V.; Brandau, S.; Chen, S.H.; Colombo, M.P.; Frey, A.B.; Greten, T.F.; Mandruzzato, S.; Murray, P.J.; Ochoa, A.; Ostrand-Rosenberg, S.; et al. Recommendations for myeloid-derived suppressor cell nomenclature and characterization standards. Nat. Commun. 2016, 7, 12150. [CrossRef] [PubMed]

36. Filipazzi, P.; Huber, V.; Rivoltini, L. Phenotype, function and clinical implications of myeloid-derived suppressor cells in cancer patients. Cancer Immunol. Immunother. 2012, 61, 255-263. [CrossRef] [PubMed] 
37. Fleming, V.; Hu, X.; Weber, R.; Nagibin, V.; Groth, C.; Altevogt, P.; Utikal, J.; Umansky, V. Targeting Myeloid-Derived Suppressor Cells to Bypass Tumor-Induced Immunosuppression. Front. Immunol. 2018, 9, 398. [CrossRef] [PubMed]

38. Condamine, T.; Dominguez, G.A.; Youn, J.I.; Kossenkov, A.V.; Mony, S.; Alicea-Torres, K.; Tcyganov, E.; Hashimoto, A.; Nefedova, Y.; Lin, C.; et al. Lectin-type oxidized LDL receptor-1 distinguishes population of human polymorphonuclear myeloid-derived suppressor cells in cancer patients. Sci. Immunol. 2016, 1. [CrossRef] [PubMed]

39. Kanterman, J.; Sade-Feldman, M.; Baniyash, M. New insights into chronic inflammation-induced immunosuppression. Semin. Cancer Biol. 2012, 22, 307-318. [CrossRef] [PubMed]

40. Condamine, T.; Gabrilovich, D.I. Molecular mechanisms regulating myeloid-derived suppressor cell differentiation and function. Trends Immunol. 2011, 32, 19-25. [CrossRef] [PubMed]

41. Yu, H.; Pardoll, D.; Jove, R. STATs in cancer inflammation and immunity: A leading role for STAT3. Nat. Rev. Cancer 2009, 9, 798-809. [CrossRef] [PubMed]

42. Sade-Feldman, M.; Kanterman, J.; Ish-Shalom, E.; Elnekave, M.; Horwitz, E.; Baniyash, M. Tumor necrosis factor-alpha blocks differentiation and enhances suppressive activity of immature myeloid cells during chronic inflammation. Immunity 2013, 38, 541-554. [CrossRef] [PubMed]

43. Lesokhin, A.M.; Hohl, T.M.; Kitano, S.; Cortez, C.; Hirschhorn-Cymerman, D.; Avogadri, F.; Rizzuto, G.A.; Lazarus, J.J.; Pamer, E.G.; Houghton, A.N.; et al. Monocytic CCR2(+) myeloid-derived suppressor cells promote immune escape by limiting activated CD8 T-cell infiltration into the tumor microenvironment. Cancer Res. 2012, 72, 876-886. [CrossRef] [PubMed]

44. Ugel, S.; De Sanctis, F.; Mandruzzato, S.; Bronte, V. Tumor-induced myeloid deviation: When myeloid-derived suppressor cells meet tumor-associated macrophages. J. Clin. Investig. 2015, 125, 3365-3376. [CrossRef] [PubMed]

45. Sawanobori, Y.; Ueha, S.; Kurachi, M.; Shimaoka, T.; Talmadge, J.E.; Abe, J.; Shono, Y.; Kitabatake, M.; Kakimi, K.; Mukaida, N.; et al. Chemokine-mediated rapid turnover of myeloid-derived suppressor cells in tumor-bearing mice. Blood 2008, 111, 5457-5466. [CrossRef] [PubMed]

46. Appay, V.; Rowland-Jones, S.L. RANTES: A versatile and controversial chemokine. Trends Immunol. 2001, 22, 83-87. [CrossRef]

47. Gielen, P.R.; Schulte, B.M.; Kers-Rebel, E.D.; Verrijp, K.; Petersen-Baltussen, H.M.; ter Laan, M.; Wesseling, P.; Adema, G.J. Increase in both CD14-positive and CD15-positive myeloid-derived suppressor cell subpopulations in the blood of patients with glioma but predominance of CD15-positive myeloid-derived suppressor cells in glioma tissue. J. Neuropathol. Exp. Neurol. 2015, 74, 390-400. [CrossRef] [PubMed]

48. Raychaudhuri, B.; Rayman, P.; Ireland, J.; Ko, J.; Rini, B.; Borden, E.C.; Garcia, J.; Vogelbaum, M.A.; Finke, J. Myeloid-derived suppressor cell accumulation and function in patients with newly diagnosed glioblastoma. Neuro-Oncology 2011, 13, 591-599. [CrossRef] [PubMed]

49. Dubinski, D.; Wolfer, J.; Hasselblatt, M.; Schneider-Hohendorf, T.; Bogdahn, U.; Stummer, W.; Wiendl, H.; Grauer, O.M. CD4+ T effector memory cell dysfunction is associated with the accumulation of granulocytic myeloid-derived suppressor cells in glioblastoma patients. Neuro-Oncology 2016, 18, 807-818. [CrossRef] [PubMed]

50. Alban, T.J.; Alvarado, A.G.; Sorensen, M.D.; Bayik, D.; Volovetz, J.; Serbinowski, E.; Mulkearns-Hubert, E.E.; Sinyuk, M.; Hale, J.S.; Onzi, G.R.; et al. Global immune fingerprinting in glioblastoma patient peripheral blood reveals immune-suppression signatures associated with prognosis. JCI Insight 2018, 3. [CrossRef] [PubMed]

51. Huang, W.J.; Chen, W.W.; Zhang, X. Glioblastoma multiforme: Effect of hypoxia and hypoxia inducible factors on therapeutic approaches. Oncol. Lett. 2016, 12, 2283-2288. [CrossRef] [PubMed]

52. Monteiro, A.R.; Hill, R.; Pilkington, G.J.; Madureira, P.A. The Role of Hypoxia in Glioblastoma Invasion. Cells 2017, 6, 45. [CrossRef] [PubMed]

53. Rong, Y.; Durden, D.L.; Van Meir, E.G.; Brat, D.J. 'Pseudopalisading' necrosis in glioblastoma: A familiar morphologic feature that links vascular pathology, hypoxia, and angiogenesis. J. Neuropathol. Exp. Neurol. 2006, 65, 529-539. [CrossRef] [PubMed]

54. Song, C.W.; Park, I.; Cho, L.C.; Yuan, J.; Dusenbery, K.E.; Griffin, R.J.; Levitt, S.H. Is indirect cell death involved in response of tumors to stereotactic radiosurgery and stereotactic body radiation therapy? Int. J. Radiat. Oncol. Biol. Phys. 2014, 89, 924-925. [CrossRef] [PubMed] 
55. Greenfield, J.P.; Cobb, W.S.; Lyden, D. Resisting arrest: A switch from angiogenesis to vasculogenesis in recurrent malignant gliomas. J. Clin. Investig. 2010, 120, 663-667. [CrossRef] [PubMed]

56. Han, Z.B.; Ren, H.; Zhao, H.; Chi, Y.; Chen, K.; Zhou, B.; Liu, Y.J.; Zhang, L.; Xu, B.; Liu, B.; et al. Hypoxia-inducible factor (HIF)-1 alpha directly enhances the transcriptional activity of stem cell factor (SCF) in response to hypoxia and epidermal growth factor (EGF). Carcinogenesis 2008, 29, 1853-1861. [CrossRef] [PubMed]

57. Kelly, B.D.; Hackett, S.F.; Hirota, K.; Oshima, Y.; Cai, Z.; Berg-Dixon, S.; Rowan, A.; Yan, Z.; Campochiaro, P.A.; Semenza, G.L. Cell type-specific regulation of angiogenic growth factor gene expression and induction of angiogenesis in nonischemic tissue by a constitutively active form of hypoxia-inducible factor 1. Circ. Res. 2003, 93, 1074-1081. [CrossRef] [PubMed]

58. Bian, X.W.; Yang, S.X.; Chen, J.H.; Ping, Y.F.; Zhou, X.D.; Wang, Q.L.; Jiang, X.F.; Gong, W.; Xiao, H.L.; Du, L.L.; et al. Preferential expression of chemokine receptor CXCR4 by highly malignant human gliomas and its association with poor patient survival. Neurosurgery 2007, 61, 570-578; discussion 578-579. [CrossRef] [PubMed]

59. Salmaggi, A.; Gelati, M.; Pollo, B.; Marras, C.; Silvani, A.; Balestrini, M.R.; Eoli, M.; Fariselli, L.; Broggi, G.; Boiardi, A. CXCL12 expression is predictive of a shorter time to tumor progression in low-grade glioma: A single-institution study in 50 patients. J. Neurooncol. 2005, 74, 287-293. [CrossRef] [PubMed]

60. Venereau, E.; Schiraldi, M.; Uguccioni, M.; Bianchi, M.E. HMGB1 and leukocyte migration during trauma and sterile inflammation. Mol. Immunol. 2013, 55, 76-82. [CrossRef] [PubMed]

61. Herskind, C.; Wenz, F.; Giordano, F.A. Immunotherapy Combined with Large Fractions of Radiotherapy: Stereotactic Radiosurgery for Brain Metastases-Implications for Intraoperative Radiotherapy after Resection. Front. Oncol. 2017, 7, 147. [CrossRef] [PubMed]

62. Kew, R.R.; Penzo, M.; Habiel, D.M.; Marcu, K.B. The IKKalpha-dependent NF-kappaB p52/RelB noncanonical pathway is essential to sustain a CXCL12 autocrine loop in cells migrating in response to HMGB1. J. Immunol. 2012, 188, 2380-2386. [CrossRef] [PubMed]

63. Schiraldi, M.; Raucci, A.; Munoz, L.M.; Livoti, E.; Celona, B.; Venereau, E.; Apuzzo, T.; De Marchis, F.; Pedotti, M.; Bachi, A.; et al. HMGB1 promotes recruitment of inflammatory cells to damaged tissues by forming a complex with CXCL12 and signaling via CXCR4. J. Exp. Med. 2012, 209, 551-563. [CrossRef] [PubMed]

64. D'Agostino, G.; Cecchinato, V.; Uguccioni, M. Chemokine Heterocomplexes and Cancer: A Novel Chapter to Be Written in Tumor Immunity. Front. Immunol. 2018, 9, 2185. [CrossRef] [PubMed]

65. Susek, K.H.; Karvouni, M.; Alici, E.; Lundqvist, A. The Role of CXC Chemokine Receptors 1-4 on Immune Cells in the Tumor Microenvironment. Front. Immunol. 2018, 9, 2159. [CrossRef] [PubMed]

66. Kalinski, P. Regulation of immune responses by prostaglandin E2. J. Immunol. 2012, 188, 21-28. [CrossRef] [PubMed]

67. Nagarsheth, N.; Wicha, M.S.; Zou, W. Chemokines in the cancer microenvironment and their relevance in cancer immunotherapy. Nat. Rev. Immunol. 2017, 17, 559-572. [CrossRef] [PubMed]

68. Deng, Y.; Cheng, J.; Fu, B.; Liu, W.; Chen, G.; Zhang, Q.; Yang, Y. Hepatic carcinoma-associated fibroblasts enhance immune suppression by facilitating the generation of myeloid-derived suppressor cells. Oncogene 2017, 36, 1090-1101. [CrossRef] [PubMed]

69. Ouyang, L.; Chang, W.; Fang, B.; Qin, J.; Qu, X.; Cheng, F. Estrogen-induced SDF-1alpha production promotes the progression of ER-negative breast cancer via the accumulation of MDSCs in the tumor microenvironment. Sci. Rep. 2016, 6, 39541. [CrossRef] [PubMed]

70. Wu, A.; Cardarelli, P.; Oyasu, M.; Menezes, D.; Ponath, P.; Cogswell, J.; Maxwell, R.; Luksik, A.; Hung, A.; Kim, E.; et al. Abstract 1736: The combination of CXCR4 and checkpoint receptor inhibition improves survival in an orthotopic murine glioma model. Cancer Res. 2018, 78, 1736. [CrossRef]

71. Rempel, S.A.; Dudas, S.; Ge, S.; Gutierrez, J.A. Identification and localization of the cytokine SDF1 and its receptor, CXC chemokine receptor 4 , to regions of necrosis and angiogenesis in human glioblastoma. Clin. Cancer Res. 2000, 6, 102-111. [PubMed]

72. Salmaggi, A.; Riva, M.; Silvani, A.; Merli, R.; Tomei, G.; Lorusso, L.; Russo, A.; Marchioni, E.; Imbesi, F.; Lombardia Neuro-oncology, G. A multicentre prospective collection of newly diagnosed glioblastoma patients in Lombardia, Italy. Neurol. Sci. 2005, 26, 227-234. [CrossRef] [PubMed] 
73. Zagzag, D.; Esencay, M.; Mendez, O.; Yee, H.; Smirnova, I.; Huang, Y.; Chiriboga, L.; Lukyanov, E.; Liu, M.; Newcomb, E.W. Hypoxia- and vascular endothelial growth factor-induced stromal cell-derived factor-1alpha/CXCR4 expression in glioblastomas: One plausible explanation of Scherer's structures. Am. J. Pathol. 2008, 173, 545-560. [CrossRef] [PubMed]

74. Petit, I.; Jin, D.; Rafii, S. The SDF-1-CXCR4 signaling pathway: A molecular hub modulating neo-angiogenesis. Trends Immunol. 2007, 28, 299-307. [CrossRef] [PubMed]

75. Wurth, R.; Bajetto, A.; Harrison, J.K.; Barbieri, F.; Florio, T. CXCL12 modulation of CXCR4 and CXCR7 activity in human glioblastoma stem-like cells and regulation of the tumor microenvironment. Front. Cell. Neurosci. 2014, 8, 144. [CrossRef] [PubMed]

76. Wang, S.C.; Yu, C.F.; Hong, J.H.; Tsai, C.S.; Chiang, C.S. Radiation therapy-induced tumor invasiveness is associated with SDF-1-regulated macrophage mobilization and vasculogenesis. PLoS ONE 2013, 8, e69182. [CrossRef] [PubMed]

77. Brown, J.M.; Recht, L.; Strober, S. The Promise of Targeting Macrophages in Cancer Therapy. Clin. Cancer Res. 2017, 23, 3241-3250. [CrossRef] [PubMed]

78. Kioi, M.; Vogel, H.; Schultz, G.; Hoffman, R.M.; Harsh, G.R.; Brown, J.M. Inhibition of vasculogenesis, but not angiogenesis, prevents the recurrence of glioblastoma after irradiation in mice. J. Clin. Investig. 2010, 120, 694-705. [CrossRef] [PubMed]

79. Tseng, D.; Vasquez-Medrano, D.A.; Brown, J.M. Targeting SDF-1/CXCR4 to inhibit tumour vasculature for treatment of glioblastomas. Br. J. Cancer 2011, 104, 1805-1809. [CrossRef] [PubMed]

80. Brown, J.M. Vasculogenesis: A crucial player in the resistance of solid tumours to radiotherapy. Br. J. Radiol. 2014, 87, 20130686. [CrossRef] [PubMed]

81. Hoellenriegel, J.; Zboralski, D.; Maasch, C.; Rosin, N.Y.; Wierda, W.G.; Keating, M.J.; Kruschinski, A.; Burger, J.A. The Spiegelmer NOX-A12, a novel CXCL12 inhibitor, interferes with chronic lymphocytic leukemia cell motility and causes chemosensitization. Blood 2014, 123, 1032-1039. [CrossRef] [PubMed]

82. Jang, T.; Savarese, T.; Low, H.P.; Kim, S.; Vogel, H.; Lapointe, D.; Duong, T.; Litofsky, N.S.; Weimann, J.M.; Ross, A.H.; et al. Osteopontin expression in intratumoral astrocytes marks tumor progression in gliomas induced by prenatal exposure to N-ethyl-N-nitrosourea. Am. J. Pathol. 2006, 168, 1676-1685. [CrossRef] [PubMed]

83. Liu, S.C.; Alomran, R.; Chernikova, S.B.; Lartey, F.; Stafford, J.; Jang, T.; Merchant, M.; Zboralski, D.; Zollner, S.; Kruschinski, A.; et al. Blockade of SDF-1 after irradiation inhibits tumor recurrences of autochthonous brain tumors in rats. Neuro-Oncology 2014, 16, 21-28. [CrossRef] [PubMed]

84. Deng, L.; Stafford, J.H.; Liu, S.C.; Chernikova, S.B.; Merchant, M.; Recht, L.; Martin Brown, J. SDF-1 Blockade Enhances Anti-VEGF Therapy of Glioblastoma and Can Be Monitored by MRI. Neoplasia 2017, 19, 1-7. [CrossRef] [PubMed]

85. Walters, M.J.; Ebsworth, K.; Berahovich, R.D.; Penfold, M.E.; Liu, S.C.; Al Omran, R.; Kioi, M.; Chernikova, S.B.; Tseng, D.; Mulkearns-Hubert, E.E.; et al. Inhibition of CXCR7 extends survival following irradiation of brain tumours in mice and rats. Br. J. Cancer 2014, 110, 1179-1188. [CrossRef] [PubMed]

86. de Groot, J.F.; Lamborn, K.R.; Chang, S.M.; Gilbert, M.R.; Cloughesy, T.F.; Aldape, K.; Yao, J.; Jackson, E.F.; Lieberman, F.; Robins, H.I.; et al. Phase II study of aflibercept in recurrent malignant glioma: A North American Brain Tumor Consortium study. J. Clin. Oncol. 2011, 29, 2689-2695. [CrossRef] [PubMed]

87. Guyon, A. CXCL12 chemokine and its receptors as major players in the interactions between immune and nervous systems. Front. Cell. Neurosci. 2014, 8, 65. [CrossRef] [PubMed]

88. Cavallero, S.; Shen, H.; Yi, C.; Lien, C.L.; Kumar, S.R.; Sucov, H.M. CXCL12 Signaling Is Essential for Maturation of the Ventricular Coronary Endothelial Plexus and Establishment of Functional Coronary Circulation. Dev. Cell 2015, 33, 469-477. [CrossRef] [PubMed]

89. Ivins, S.; Chappell, J.; Vernay, B.; Suntharalingham, J.; Martineau, A.; Mohun, T.J.; Scambler, P.J. The CXCL12/CXCR4 Axis Plays a Critical Role in Coronary Artery Development. Dev. Cell 2015, 33, 455-468. [CrossRef] [PubMed]

90. Li, W.; Kohara, H.; Uchida, Y.; James, J.M.; Soneji, K.; Cronshaw, D.G.; Zou, Y.R.; Nagasawa, T.; Mukouyama, Y.S. Peripheral nerve-derived CXCL12 and VEGF-A regulate the patterning of arterial vessel branching in developing limb skin. Dev. Cell 2013, 24, 359-371. [CrossRef] [PubMed] 
91. Ma, Q.; Jones, D.; Borghesani, P.R.; Segal, R.A.; Nagasawa, T.; Kishimoto, T.; Bronson, R.T.; Springer, T.A. Impaired B-lymphopoiesis, myelopoiesis, and derailed cerebellar neuron migration in CXCR4- and SDF-1-deficient mice. Proc. Natl. Acad. Sci. USA 1998, 95, 9448-9453. [CrossRef] [PubMed]

92. Nagasawa, T.; Hirota, S.; Tachibana, K.; Takakura, N.; Nishikawa, S.; Kitamura, Y.; Yoshida, N.; Kikutani, H.; Kishimoto, T. Defects of B-cell lymphopoiesis and bone-marrow myelopoiesis in mice lacking the CXC chemokine PBSF/SDF-1. Nature 1996, 382, 635-638. [CrossRef] [PubMed]

93. Takabatake, Y.; Sugiyama, T.; Kohara, H.; Matsusaka, T.; Kurihara, H.; Koni, P.A.; Nagasawa, Y.; Hamano, T.; Matsui, I.; Kawada, N.; et al. The CXCL12 (SDF-1)/CXCR4 axis is essential for the development of renal vasculature. J. Am. Soc. Nephrol. 2009, 20, 1714-1723. [CrossRef] [PubMed]

94. Janssens, R.; Struyf, S.; Proost, P. The unique structural and functional features of CXCL12. Cell. Mol. Immunol. 2018, 15, 299-311. [CrossRef] [PubMed]

95. Pawig, L.; Klasen, C.; Weber, C.; Bernhagen, J.; Noels, H. Diversity and Inter-Connections in the CXCR4 Chemokine Receptor/Ligand Family: Molecular Perspectives. Front. Immunol. 2015, 6, 429. [CrossRef] [PubMed]

96. Massara, M.; Bonavita, O.; Mantovani, A.; Locati, M.; Bonecchi, R. Atypical chemokine receptors in cancer: Friends or foes? J. Leukoc. Biol. 2016, 99, 927-933. [CrossRef] [PubMed]

97. Odemis, V.; Lipfert, J.; Kraft, R.; Hajek, P.; Abraham, G.; Hattermann, K.; Mentlein, R.; Engele, J. The presumed atypical chemokine receptor CXCR7 signals through $\mathrm{G}(\mathrm{i} / \mathrm{o})$ proteins in primary rodent astrocytes and human glioma cells. Glia 2012, 60, 372-381. [CrossRef] [PubMed]

98. Handel, T.M.; Johnson, Z.; Crown, S.E.; Lau, E.K.; Proudfoot, A.E. Regulation of protein function by glycosaminoglycans-As exemplified by chemokines. Annu. Rev. Biochem. 2005, 74, 385-410. [CrossRef] [PubMed]

99. Heckmann, D.; Maier, P.; Laufs, S.; Li, L.; Sleeman, J.P.; Trunk, M.J.; Leupold, J.H.; Wenz, F.; Zeller, W.J.; Fruehauf, S.; et al. The disparate twins: A comparative study of CXCR4 and CXCR7 in SDF-1alpha-induced gene expression, invasion and chemosensitivity of colon cancer. Clin. Cancer Res. 2014, 20, 604-616. [CrossRef] [PubMed]

100. Kaplan, R.N.; Psaila, B.; Lyden, D. Niche-to-niche migration of bone-marrow-derived cells. Trends Mol. Med. 2007, 13, 72-81. [CrossRef] [PubMed]

101. Li, M.; Ransohoff, R.M. The roles of chemokine CXCL12 in embryonic and brain tumor angiogenesis. Semin. Cancer Biol. 2009, 19, 111-115. [CrossRef] [PubMed]

102. Ozen, I.; Boix, J.; Paul, G. Perivascular mesenchymal stem cells in the adult human brain: A future target for neuroregeneration? Clin. Transl. Med. 2012, 1, 30. [CrossRef] [PubMed]

103. Filatova, A.; Acker, T.; Garvalov, B.K. The cancer stem cell niche(s): The crosstalk between glioma stem cells and their microenvironment. Biochim. Biophys. Acta 2013, 1830, 2496-2508. [CrossRef] [PubMed]

104. Hira, V.V.V.; Aderetti, D.A.; van Noorden, C.J.F. Glioma Stem Cell Niches in Human Glioblastoma Are Periarteriolar. J. Histochem. Cytochem. 2018, 66, 349-358. [CrossRef] [PubMed]

105. Ehtesham, M.; Mapara, K.Y.; Stevenson, C.B.; Thompson, R.C. CXCR4 mediates the proliferation of glioblastoma progenitor cells. Cancer Lett. 2009, 274, 305-312. [CrossRef] [PubMed]

106. Rao, S.; Sengupta, R.; Choe, E.J.; Woerner, B.M.; Jackson, E.; Sun, T.; Leonard, J.; Piwnica-Worms, D.; Rubin, J.B. CXCL12 mediates trophic interactions between endothelial and tumor cells in glioblastoma. PLoS ONE 2012, 7, e33005. [CrossRef] [PubMed]

107. Sciaccaluga, M.; Fioretti, B.; Catacuzzeno, L.; Pagani, F.; Bertollini, C.; Rosito, M.; Catalano, M.; D’Alessandro, G.; Santoro, A.; Cantore, G.; et al. CXCL12-induced glioblastoma cell migration requires intermediate conductance Ca2+-activated K+ channel activity. Am. J. Physiol. Cell Physiol. 2010, 299, C175-C184. [CrossRef] [PubMed]

108. Edalat, L.; Stegen, B.; Klumpp, L.; Haehl, E.; Schilbach, K.; Lukowski, R.; Kuhnle, M.; Bernhardt, G.; Buschauer, A.; Zips, D.; et al. BK K+ channel blockade inhibits radiation-induced migration/brain infiltration of glioblastoma cells. Oncotarget 2016, 7, 14259-14278. [CrossRef] [PubMed]

109. Cheng, L.; Huang, Z.; Zhou, W.; Wu, Q.; Donnola, S.; Liu, J.K.; Fang, X.; Sloan, A.E.; Mao, Y.; Lathia, J.D.; et al. Glioblastoma stem cells generate vascular pericytes to support vessel function and tumor growth. Cell 2013, 153, 139-152. [CrossRef] [PubMed] 
110. Lee, J.H.; Lee, J.E.; Kahng, J.Y.; Kim, S.H.; Park, J.S.; Yoon, S.J.; Um, J.Y.; Kim, W.K.; Lee, J.K.; Park, J.; et al. Human glioblastoma arises from subventricular zone cells with low-level driver mutations. Nature 2018, 560, 243-247. [CrossRef] [PubMed]

111. Goffart, N.; Lombard, A.; Lallemand, F.; Kroonen, J.; Nassen, J.; Di Valentin, E.; Berendsen, S.; Dedobbeleer, M.; Willems, E.; Robe, P.; et al. CXCL12 mediates glioblastoma resistance to radiotherapy in the subventricular zone. Neuro-Oncology 2016. [CrossRef] [PubMed]

112. Liu, Y.; Shen, Y.; Sun, T.; Yang, W. Mechanisms regulating radiosensitivity of glioma stem cells. Neoplasma 2017, 64, 655-665. [CrossRef] [PubMed]

113. Teicher, B.A.; Fricker, S.P. CXCL12 (SDF-1)/CXCR4 pathway in cancer. Clin. Cancer Res. 2010, 16, $2927-2931$. [CrossRef] [PubMed]

114. Peled, A.; Klein, S.; Beider, K.; Burger, J.A.; Abraham, M. Role of CXCL12 and CXCR4 in the pathogenesis of hematological malignancies. Cytokine 2018, 109, 11-16. [CrossRef] [PubMed]

115. Barbieri, F.; Bajetto, A.; Thellung, S.; Wurth, R.; Florio, T. Drug design strategies focusing on the CXCR4/CXCR7/CXCL12 pathway in leukemia and lymphoma. Expert Opin. Drug Discov. 2016, 11, 1093-1109. [CrossRef] [PubMed]

116. Kryczek, I.; Lange, A.; Mottram, P.; Alvarez, X.; Cheng, P.; Hogan, M.; Moons, L.; Wei, S.; Zou, L.; Machelon, V.; et al. CXCL12 and vascular endothelial growth factor synergistically induce neoangiogenesis in human ovarian cancers. Cancer Res. 2005, 65, 465-472. [PubMed]

117. Porcile, C.; Bajetto, A.; Barbieri, F.; Barbero, S.; Bonavia, R.; Biglieri, M.; Pirani, P.; Florio, T.; Schettini, G. Stromal cell-derived factor-1alpha (SDF-1alpha/CXCL12) stimulates ovarian cancer cell growth through the EGF receptor transactivation. Exp. Cell Res. 2005, 308, 241-253. [CrossRef] [PubMed]

118. Dillenburg-Pilla, P.; Patel, V.; Mikelis, C.M.; Zarate-Blades, C.R.; Doci, C.L.; Amornphimoltham, P.; Wang, Z.; Martin, D.; Leelahavanichkul, K.; Dorsam, R.T.; et al. SDF-1/CXCL12 induces directional cell migration and spontaneous metastasis via a CXCR4/Galphai/mTORC1 axis. FASEB J. 2015, 29, 1056-1068. [CrossRef] [PubMed]

119. Zeelenberg, I.S.; Ruuls-Van Stalle, L.; Roos, E. The chemokine receptor CXCR4 is required for outgrowth of colon carcinoma micrometastases. Cancer Res. 2003, 63, 3833-3839. [PubMed]

120. Jung, M.J.; Rho, J.K.; Kim, Y.M.; Jung, J.E.; Jin, Y.B.; Ko, Y.G.; Lee, J.S.; Lee, S.J.; Lee, J.C.; Park, M.J. Upregulation of CXCR4 is functionally crucial for maintenance of stemness in drug-resistant non-small cell lung cancer cells. Oncogene 2013, 32, 209-221. [CrossRef] [PubMed]

121. Cioffi, M.; D'Alterio, C.; Camerlingo, R.; Tirino, V.; Consales, C.; Riccio, A.; Ierano, C.; Cecere, S.C.; Losito, N.S.; Greggi, S.; et al. Identification of a distinct population of CD133(+)CXCR4(+) cancer stem cells in ovarian cancer. Sci. Rep. 2015, 5, 10357. [CrossRef] [PubMed]

122. Burns, J.M.; Summers, B.C.; Wang, Y.; Melikian, A.; Berahovich, R.; Miao, Z.; Penfold, M.E.; Sunshine, M.J.; Littman, D.R.; Kuo, C.J.; et al. A novel chemokine receptor for SDF-1 and I-TAC involved in cell survival, cell adhesion, and tumor development. J. Exp. Med. 2006, 203, 2201-2213. [CrossRef] [PubMed]

123. Miao, Z.; Luker, K.E.; Summers, B.C.; Berahovich, R.; Bhojani, M.S.; Rehemtulla, A.; Kleer, C.G.; Essner, J.J.; Nasevicius, A.; Luker, G.D.; et al. CXCR7 (RDC1) promotes breast and lung tumor growth in vivo and is expressed on tumor-associated vasculature. Proc. Natl. Acad. Sci. USA 2007, 104, 15735-15740. [CrossRef] [PubMed]

124. Fahham, D.; Weiss, I.D.; Abraham, M.; Beider, K.; Hanna, W.; Shlomai, Z.; Eizenberg, O.; Zamir, G.; Izhar, U.; Shapira, O.M.; et al. In vitro and in vivo therapeutic efficacy of CXCR4 antagonist BKT140 against human non-small cell lung cancer. J. Thorac. Cardiovasc. Surg. 2012, 144, 1167-1175. [CrossRef] [PubMed]

125. Singh, S.; Srivastava, S.K.; Bhardwaj, A.; Owen, L.B.; Singh, A.P. CXCL12-CXCR4 signalling axis confers gemcitabine resistance to pancreatic cancer cells: A novel target for therapy. Br. J. Cancer 2010, 103, 1671-1679. [CrossRef] [PubMed]

126. Ma, Y.; Hwang, R.F.; Logsdon, C.D.; Ullrich, S.E. Dynamic mast cell-stromal cell interactions promote growth of pancreatic cancer. Cancer Res. 2013, 73, 3927-3937. [CrossRef] [PubMed]

127. Chen, Y.; Huang, Y.; Reiberger, T.; Duyverman, A.M.; Huang, P.; Samuel, R.; Hiddingh, L.; Roberge, S.; Koppel, C.; Lauwers, G.Y.; et al. Differential effects of sorafenib on liver versus tumor fibrosis mediated by stromal-derived factor 1 alpha/C-X-C receptor type 4 axis and myeloid differentiation antigen-positive myeloid cell infiltration in mice. Hepatology 2014, 59, 1435-1447. [CrossRef] [PubMed] 
128. Huang, E.H.; Singh, B.; Cristofanilli, M.; Gelovani, J.; Wei, C.; Vincent, L.; Cook, K.R.; Lucci, A. A CXCR4 antagonist CTCE-9908 inhibits primary tumor growth and metastasis of breast cancer. J. Surg. Res. 2009, 155, 231-236. [CrossRef] [PubMed]

129. Smith, M.C.; Luker, K.E.; Garbow, J.R.; Prior, J.L.; Jackson, E.; Piwnica-Worms, D.; Luker, G.D. CXCR4 regulates growth of both primary and metastatic breast cancer. Cancer Res. 2004, 64, 8604-8612. [CrossRef] [PubMed]

130. Darash-Yahana, M.; Pikarsky, E.; Abramovitch, R.; Zeira, E.; Pal, B.; Karplus, R.; Beider, K.; Avniel, S.; Kasem, S.; Galun, E.; et al. Role of high expression levels of CXCR4 in tumor growth, vascularization, and metastasis. FASEB J. 2004, 18, 1240-1242. [CrossRef] [PubMed]

131. Taichman, R.S.; Cooper, C.; Keller, E.T.; Pienta, K.J.; Taichman, N.S.; McCauley, L.K. Use of the stromal cell-derived factor-1/CXCR4 pathway in prostate cancer metastasis to bone. Cancer Res. 2002, 62, 1832-1837. [PubMed]

132. Porvasnik, S.; Sakamoto, N.; Kusmartsev, S.; Eruslanov, E.; Kim, W.J.; Cao, W.; Urbanek, C.; Wong, D.; Goodison, S.; Rosser, C.J. Effects of CXCR4 antagonist CTCE-9908 on prostate tumor growth. Prostate 2009, 69, 1460-1469. [CrossRef] [PubMed]

133. Sun, Y.X.; Schneider, A.; Jung, Y.; Wang, J.; Dai, J.; Wang, J.; Cook, K.; Osman, N.I.; Koh-Paige, A.J.; Shim, H.; et al. Skeletal localization and neutralization of the SDF-1(CXCL12)/CXCR4 axis blocks prostate cancer metastasis and growth in osseous sites in vivo. J. Bone Miner. Res. 2005, 20, 318-329. [CrossRef] [PubMed]

134. Feig, C.; Jones, J.O.; Kraman, M.; Wells, R.J.; Deonarine, A.; Chan, D.S.; Connell, C.M.; Roberts, E.W.; Zhao, Q.; Caballero, O.L.; et al. Targeting CXCL12 from FAP-expressing carcinoma-associated fibroblasts synergizes with anti-PD-L1 immunotherapy in pancreatic cancer. Proc. Natl. Acad. Sci. USA 2013, 110, 20212-20217. [CrossRef] [PubMed]

135. Chen, Y.; Ramjiawan, R.R.; Reiberger, T.; Ng, M.R.; Hato, T.; Huang, Y.; Ochiai, H.; Kitahara, S.; Unan, E.C.; Reddy, T.P.; et al. CXCR4 inhibition in tumor microenvironment facilitates anti-programmed death receptor-1 immunotherapy in sorafenib-treated hepatocellular carcinoma in mice. Hepatology 2015, 61, 1591-1602. [CrossRef] [PubMed]

136. Chaudary, N.; Pintilie, M.; Jelveh, S.; Lindsay, P.; Hill, R.P.; Milosevic, M. Plerixafor Improves Primary Tumor Response and Reduces Metastases in Cervical Cancer Treated with Radio-Chemotherapy. Clin. Cancer Res. 2017, 23, 1242-1249. [CrossRef] [PubMed]

137. Thomas, R.P.; Nagpal, S.; Iv, M.; Soltys, S.G.; Bertrand, S.; Pelpola, J.S.; Yang, J.; Ball, R.L.; Brown, M.; Recht, L.D. CXCR4 blockade at the end of irradiation to improve local control of glioblastoma (GBM). J. Clin. Oncol. 2018, 36. [CrossRef]

138. Lee, E.Q.; Duda, D.G.; Muzikansky, A.; Gerstner, E.R.; Kuhn, J.G.; Reardon, D.A.; Nayak, L.; Norden, A.D.; Doherty, L.; LaFrankie, D.; et al. Phase I and Biomarker Study of Plerixafor and Bevacizumab in Recurrent High-Grade Glioma. Clin. Cancer Res. 2018, 24, 4643-4649. [CrossRef] [PubMed]

139. Ludwig, H.; Weisel, K.; Petrucci, M.T.; Leleu, X.; Cafro, A.M.; Garderet, L.; Leitgeb, C.; Foa, R.; Greil, R.; Yakoub-Agha, I.; et al. Olaptesed pegol, an anti-CXCL12/SDF-1 Spiegelmer, alone and with bortezomib-dexamethasone in relapsed/refractory multiple myeloma: A Phase Ila Study. Leukemia 2017, 31, 997-1000. [CrossRef] [PubMed]

140. Hattermann, K.; Held-Feindt, J.; Lucius, R.; Muerkoster, S.S.; Penfold, M.E.; Schall, T.J.; Mentlein, R. The chemokine receptor CXCR7 is highly expressed in human glioma cells and mediates antiapoptotic effects. Cancer Res. 2010, 70, 3299-3308. [CrossRef] [PubMed]

141. Maderna, E.; Salmaggi, A.; Calatozzolo, C.; Limido, L.; Pollo, B. Nestin, PDGFRbeta, CXCL12 and VEGF in glioma patients: Different profiles of (pro-angiogenic) molecule expression are related with tumor grade and may provide prognostic information. Cancer Biol. Ther. 2007, 6, 1018-1024. [CrossRef] [PubMed]

(C) 2019 by the authors. Licensee MDPI, Basel, Switzerland. This article is an open access article distributed under the terms and conditions of the Creative Commons Attribution (CC BY) license (http://creativecommons.org/licenses/by/4.0/). 